question of fine adjustments to existing knowledge, while in the latter new developments may only be expected by going to extreme temperatures and pressures with adaptations of existing techniques. To illustrate the importance of noise in daily life and methods of measuring it, the regional authorities of Baden-Würtemburg opened to the public an exhibit in a Stuttgart Museum entitled "Weniger Lärm".

It was announced that the next international congress would be held in Copenhagen in 1962, and if the number of participants should continue to increase at the present rate this will involve the local organiza. tion in much hard thinking about how they are to lodge them and deal with the reading of the many papers expected.

This situation is not peculiar to acousties, but there is a possibility of splitting the auditory into roughly equal numbers of those concerned with physical and physiological acoustics and those interested mainly in architectural, musical and industrial applications. Perhaps two congresses en suite with a week-end of social activities and excursions sandwiched between them might overcome some of the difficulties of organization.

The proceedings of the congress are to be published in book form by Elsevier Press. E. G. Richardson

\title{
PHOTOGRAPHY IN THE INTERNATIONAL GEOPHYSICAL YEAR
}

A SYMPOSIUM on photography in the International Geophysical Year was held in Edinburgh on June 6, under the auspices of the Scientific and Technical Group of the Royal Photographic Society of Great Britain.

Following his address of welcome on behalf of the University of Edinburgh, Sir Edward Appleton stated that he believed the effect of the International Geophysical Year on association between geophysicists would be a permanent one, and recalled the descent of the recent great collaboration from earlier International Polar Years. He then described some of the ionospheric work carried out during the International Geophysical Year and directed attention to the valuable part played by photography in making possible permanent records. In conclusion, he spoke of the most striking discovery of the Van Allen radiation belt. Miss Harker, president of the Royal Photographic Society, replied and went on to discuss the wide compass of photography, illustrated by the nature of the subject of the symposium.

The study of aurorae by all-sky cameras was described by Dr. G. M. Thomas, of the Balfour Stewart Auroral Laboratory. He pointed out that remoteness and erratic occurrence make auroral data scanty, and that any casual collection of data is bad statistically. However, full-time observation is a costly matter, but sky cameras could provide the necessary supplement to visual observation. A system was described consisting of a motion picture camera viewing a large convex mirror, the mirror being heated to keep off frost and snow, and a calendar and watch placed in the field of view. Timing of the camera's function was provided by a synchronous motor. A film illustrating the systematic motion of the aurorae was shown. It is of great importance to correlate the sudden alterations which occur with changes in the magnetic field at the ground.

The next contribution reviewed some of the contributions of photographic techniques to rocket and satellite work, and deseribed particularly the ballistic cameras developed at University College, London, for the 'grenade' experiment. This is a method of finding upper-air winds and temperatures by measuring the time of travel of sound from grenades fired from an ascending rocket. The special function of photography here is to locate the grenade bursts with great precision. When the experiment is carried out in daylight, special techniques are necessary to obtain rapid triggering of the shutters by light from the grenades. Experiments under preparation for X-ray observation of the Sun and ultra-violet astronomy of the stars were also described. The latter work is being conducted in collaboration with Dr. H. E. Butler, of the Royal Observatory, Edinburgh, who then described his use of a technique, due originally to Dr. Baker, of the same Observatory, to bring up the detail of very faint interstellar absorption lines. Basically, the problem is to bring out the signal from the 'background noise' grain in the plates, and it is accomplished by careful photometering and summing of the results from many plates, together with subtraction from a standard spectrum to remove the emission structure. The results were extremely impressive, as indeed was the amount of work required to obtain them; a million separate readings from twenty-seven different exposures were obtained.

Dr. C. J. Waddington, of the University of Bristol, described his subject as the study of the 'footprints' of cosmic ray particles. Due to the vastness of his subject, he limited his discussion to an extended series of high-altitude balloon flights with nuclear emulsions made with the avowed intention of monitoring the long-term variation of the primary cosmic radiation. Seventy-three balloon flights were made by a group led by Prof. E. P. Ney (Minnesota). A typical payload consisted of a dozen 4 in. $\times 4$ in. $600 \mu$ Ilford G.5 emulsion plates, together with a single counter and an ion chamber. Although protons are more abundant, $\alpha$-particles were chosen for the study for a variety of reasons, among which were the complications of an albedo of protons from disintegrations and the greater ease of finding and counting $\alpha$-particle tracks in nuclear emulsions. The results of these observations are still being analysed, but already it is clear that differences in the variation of $\alpha$-particle and proton flux after a solar flare should ultimately throw light on the properties of the space between us and the Sun.

A paper by Dr. W. I. Arvegwitch, of the U.S.S.R. Academy of Sciences Institute of Geography, was read for him in his absence. His paper discussed photo-topographic methods used by his Institute for the study of glaciers. For more than a decade glaciation has been studied by aerial photography although stereo-photogrammetric surveys from the 
ground are still considered to be the most reliable means of recording the state and behaviour of glaciers. Recently, however, aerial photography, with its advantage of the avoidance of 'dead areas' due to obstacles, has been applied to the study of glacier dynamies. Unfortunately, the paper gave no information on the experimental equipment, either aerial cameras or the new Soviet stereograph " $S D-1$ ", which was claimed to be notable for its precision, having a relative mean-square error of vertical control in the neighbourhood of $1 / 3,000$. It was a conclusion of the paper that aerial photography could greatly speed up a survey, especially with the use of helicopters, but that no single method in phototopography is appropriate in every situation.

The meeting ended with projection of the Russian research film, "North Pole", showing Soviet scientific research in the Arctic and describing the results of oceanographic and meteorological work. Of special interest were sequences showing the circulatory movements of water and ice-flows about the Pole.

R. L. F. BOYD

\section{GLASSHOUSE CROPS RESEARCH INSTITUTE}

\section{OPEN DAY}

$\mathrm{T}$ HE Glasshouse Crops Research Institute, Littlehampton, Sussex, held its annual open day on June 10 when nearly two hundred visitors attended. The laboratories were open for inspection during the morning, and after lunch, at which the director, Mr. F. W. Toovey, reported on the Institute's progress during the past year, a series of demonstrations were arranged in the experimental glasshouses and mushroom sheds.

In tomato variety trials by the Plant Breeding Section (Mr. L. A. Darby) special interest was shown in hybrids with the 'Baby Lea' variety, some of which are in the $F_{5}$ generation and beginning to breed reasonably true. This variety has a compact habit of growth (short internodes), and an attempt is being made to incorporate this habit into known good combining varieties with the aim of producing an $F_{1}$ hybrid of good early and total yield, bearing high-quality fruit, and which will not suffer from the excessive vigour of hybrids at present grown commercially. A cucumber-breeding trial, which was also demonstrated, tests the value of $F_{1}$ hybrids for commercial use with special reference to early and total yields, and to fruit quality.

The Plant Physiology Department (Dr. E. R. Leonard) showed the concluding stages of a time-ofplanting experiment carried out as part of its growth analysis studies on the tomato. Previous work has suggested the influence of day-length on the growth of all the major organs of the plant, including the roots, and in order to investigate this more fully sowings at one of the dates included in the main time-of-planting experiment have also been carried out at three other centres in the British Isles, ranging from Guernsey in the Channel Islands to Auchineruive in Scotland, and in Malta and Finland. A prototype temperature-controlled glass cabinet, erected in a glasshouse, for studying the growth of tomato plants under controlled day-length throughout a cropping season was also on display. Another exhibit was equipment for the production of artificial temperature gradients across a tomato fruit in connexion with the Department's investigation of fruit ripening disorders, including those loosely referred to as 'blotchy ripening'.

The Chemistry Department's programme, under Dr. G. W. Winsor, includes a comprehensive study of the nutrition of the tomato, and a wide range of glasshouse experiments was on view. These comprise a basic factorial trial, testing nitrogen, phosphorus, potassium, calcium and magnesium, two experiments on liquid feeding, and an investigation of the effect of magnesium deficiency on yield and its control by applying magnesium sulphate to the soil or to the foliage. Determinations of nutrient uptake are a special feature of these experiments. Laboratory studies of tomato fruit composition were also demonstrated; these have particular reference to fruit-ripening disorders and may shed light on factors determining flavour. Changes in the enzyme activity associated with ripening are also being investigated. The Department also works on other glasshouse crops, and of topical interest were the studies being made of the effects of manganese toxicity on tomatoes, lettuce and carnations. A factorial nutritional trial on carnations, testing three levels of nitrogen and potassium in the presence or absence of added phosphorus, magnesium or calcium, was also on view. With the cultivated mushroom certain eultural problems are studied, particular attention being paid to various factors of the casing layer in relation to fruiting; evidence has accumulated that total moisture stress has an important influence on fruiting. An investigation of the effect of factors of the atmospheric environment on mushroom growth is also about to be taken up, and a prototype controlledenvironment chamber for this was on view.

The Plant Pathology Division (under Dr. L. Broadbent) demonstrated the work of its three Departments, Entomology (Dr. N. W. Hussey), Mycology (Mr. P. H. Williams) and Virology (Mr. M. Hollings). At present the Entomology Department is devoting a great deal of attention to cecids affecting the cultivated mushroom; observations on their lifehistory were illustrated, and results were presented on the very rapid rate of increase of the larvæ in compost. The results of experiments on the control of cecids by the application of $\gamma-\mathrm{BHC}$ to compost or casing were also displayed. The Mycology Department showed aspects of its work on the Didymella stem rot of the tomato, on cucumber mildew, on carnation wilts and on mushroom fruiting disorders. In connexion with the investigation of carnation wilt diseases, a glasshouse experiment on the survival of the pathogens in soil and plant roots was in progress; this involves the growing of carnations, chrysanthemums and tomatoes in rotation in concrete-lined beds to see whether the wilt organisms can be carried over on hosts other than the carnation, even though producing no visible symptoms on those hosts. Mushroom fruiting disorders, associated with greatly reduced cropping, have caused much concern to the 